\title{
Microbiological analysis and determination of antimicrobial traits of green banana (Musa spp.) and papaya (Carica papaya)
}

\author{
Nusrat Jahan ${ }^{1}$, Rashed Noor ${ }^{2} *$ and Saurab Kishore Munshi ${ }^{1}$ \\ ${ }^{1}$ Department of Microbiology, Stamford University Bangladesh, 51 Siddeswari Road, Dhaka 1217, Bangladesh \\ ${ }^{2}$ School of Life Sciences (SLS), Independent University, Bangladesh (IUB), Plot 16, Block B, Aftabuddin Ahmed \\ Road, Bashundhara, Dhaka 1229, Bangladesh
}

Received 09 September 2018/Accepted 08 October 2018

\begin{abstract}
Green banana (Musa spp.) and papaya (Carica papaya), which are commonly consumed as vegetables, are fruits with lots of health benefits. Due to their various medicinal applications, both the fruits are likely to contain antimicrobial properties. In this regard, present study was undertaken to determine the microbiological quality as well as the anti-bacterial traits of fresh green banana and papaya. To serve the purpose, a total of 12 samples (6 green bananas and 6 green papaya) were collected from different local and super shops as well from cultivation land of some villages of Bangladesh. The samples contained the microbial contamination with viable bacteria and fungi up to $10^{7} \mathrm{cfu} / \mathrm{g}$ and $10^{3}$ cfu/g. Among the pathogenic bacteria, Staphylococcus spp. Pseudomonas spp. and Vibrio spp. were predominant as found in most of the samples in average of $10^{2} \mathrm{cfu} / \mathrm{g}$. Whereas Escherichia coli, Salmonella spp. and Shigella spp. were totally absent in all the samples. On the other hand, Klebsiella spp. was present in same samples. Additionally, the anti-bacterial poverties of the samples were chalked out. The in-vitro antimicrobial activities of the ethanolic, methanolic and hot water extracts of the samples were noticeably found against all the tested bacteria. Overall, present study revealed that both the green fruit samples were highly contaminated although they have antimicrobial activities. Thus, consumers' awareness on the risk of consuming pathogen contaminated vegetables needs to be re-awakened and further investigations are required for potential antimicrobial properties.
\end{abstract}

Key words: Green banana; Green papaya; Microbiological analysis; Antibacterial activity

The consumption of fresh fruits has increased around the world on account of the nutritional value and the ease of availability (1). Raw fruits and vegetables confer healthy human life by providing proteins, carbohydrates and many vitamins, minerals (2). However, in current years, food safety concern of these fresh produce is one of the major concern in the developing countries $(3,4)$. In nutritional, health, and economic point of view, the consumption of fresh vegetables and fruits need to be increased by ensuring food safety.

Banana (Musa spp.) is one of popular tropical fruits cultivated in over 122 countries and is ranked as third most cultivated crops worldwide (5-7). Green banana or plantain represents an agriculture product with $22 \%$ carbohydrates of total fruit weight and constitutes largely of vitamins A, B6, C, minerals and dietary fibre $(8,9)$. This vegetable is known to provide significant quantity of carbohydrates and calories in our daily diet globally (10). On the other hand, papaya (Carica papaya) is a special fruit crop having high nutritional value and potential for both fresh and processed market uses. Papaya exceeds apple, peach, and grapes in

*Corresponding Author: Mailing address. Dr. Rashed Noor, Associate Professor, School of Life Sciences (SLS), Independent University, Bangladesh (IUB), Plot 16, Block B, Aftabuddin Ahmed Road, Bashundhara, Dhaka 1229 , Bangladesh; E-mail: rashednoor@iub.edu.bd. vitamins, minerals, amino acid, and food energy values as a fruit source. The green fruit is evident to comprise of protein, fat, carbohydrate, fiber, ash, $\mathrm{Ca}, \mathrm{P}, \mathrm{Fe}, \mathrm{Na}, \mathrm{K}$, betacarotene equivalent, thiamine, riboflavin, niacin, ascorbic acid and Vitamin E. It has also been found to contain sinigrin, the enzyme myrosin, and carpasemine (11).

Various vegetables get contaminated with microorganisms largely from different factors such as resident microflora in the soil, application of nonresident microflora via animal manures, irrigation water or sewage, transportation and handling by individual retailers $(1,12,13)$. Six pathogens such as Escherichia coli, Listeria monocytogenes, Campylobacter jejuni, Clostridium perfringens, Salmonella spp. and Staphylococcus aureus have been estimated to account for approximately 7 million cases of food borne illnesses (14). Especially in the developing countries use of untreated waste- water and manure as fertilizers for the production of vegetables is regarded as a major contributing factor to contamination $(3,4)$. Fresh vegetables and fruits are usually washed or treated specifically to minimize microbial load. However, the lack of effective antimicrobial treatments at any step from planting to consumption results in the presence of contaminating pathogens in the final product (1).

Banana both as fruit and vegetable comprises of many 
different antioxidant and antimicrobial components (15). Banana could be a good source of natural antioxidant against cancer and heart disease (16). Antifungal and antibiotic traits are found in the peel and pulp of fully ripe bananas. Fungicidal activity in the peel and pulp of green fruits is found against a fungus disease of tomato plants (17). Norepinephrine, dopamine, and serotonin are also present in the peel and pulp of bananas $(15,16)$. On contrary, the leaves, fruits and latex obtained from the papaya plant have medicinal uses. The fruit has been found to contain certain immunestimulating and anti-oxidant agents. Papaya has many biologically active compounds including chymopapain and papain, which helps in digestion (18). Papaya root, seed and leaf extracts possess highly anti-tumor and pesticidal properties (19). The green papaya is used for the cure of ulcer and impotence (20). The unripe fruits have uses as antiseptic, in cleansing the intestines from bacteria and enabling the intestine to absorb vitamin and minerals especially vitamin B12 (21). Secondary metabolites such as alkaloids, flavonoids, saponins and tannins in green papaya are serving as a potent free radical scavenger and are antimicrobial in action (22).

Considering all these fact, the study was carried out to investigate the microbiological quality and antimicrobial traits of fresh green bananas and papaya. Samples were collected from different areas in Bangladesh and tested for the presence of antibacterial activity through agar well diffusion method following ethanolic, methanolic and hot water extraction.

\section{MATERIALS AND METHODS}

Study area and sampling. A total of 12 green bananas and papaya samples, 4 from local market in Dhaka city, 4 from village market and 4 from super shops were randomly collected from different types of shops. All the samples were prepared, processed and analyzed during the period of $1^{\text {st }}$ March 2017 to $6^{\text {th }}$ April 2017 in Microbiology Laboratory of Stamford University Bangladesh.

Sample processing. The samples were processed following standard methods. $25 \mathrm{gm}$ of green fruit samples weighted and added into $75 \mathrm{ml}$ of normal saline in sterile blender and a homogenized mixture of sample as prepared to obtain $10^{-1}$ dilution of the sample shake well by vortex mixture. Then $1 \mathrm{ml}$ from $10^{-1}$ dilution was transferred to $9 \mathrm{ml}$ of normal saline to make $10^{-2}$ dilution and using the same procedure, sample was diluted to $10^{-5}$ dilution (Cappucino and Shermen, 1996, Sharmin et al. 2014, Das et al. 2017, ; Acharjee et al., 2014, Mrjan et al., 2014, Ahmed et al., 2013; Noor et al. 2013). By following serial dilution technique the blend samples were spread on different types of media for enumeration of bacterial load.

Inoculation and enumeration of microorganisms. Spread plate technique was used to inoculate the samples on various culture media for enumeration of microorganisms. Melted medium is poured in a petri dish and allow solidifying. For the growth of total viable bacteria and fungi, $0.1 \mathrm{ml}$ of samples from $10^{-3}$ and $10^{-5}$ dilutions was added to nutrient agar medium (NA) and Sabouraud's dextrose agar (SDA) plates. From dilution $10^{-3}, 0.1 \mathrm{ml}$ sample was added to MacConkey agar (MAC), Mannitol salt agar (MSA) and Pseudomonas agar (PA) for the isolation and enumeration of specific bacterial pathogens. All media were incubated at $37{ }^{\circ} \mathrm{C}$ for 24 hours and SDA were incubated at $25{ }^{\circ} \mathrm{C}$ for 24-48 hours for total viable fungi (23-29).

For the enrichment of Salmonella, Shigella, and vibrio spp., $10 \mathrm{ml}$ of sample was transferred into $90 \mathrm{ml}$ of selenite cysteine broth (SCB) and alkaline peptone water (APW), respectively and incubated at $37{ }^{\circ} \mathrm{C}$ for 6 hours (30-33). After incubation , the samples were diluted up to $10^{-6}$ and then $0.1 \mathrm{ml}$ of samples from the dilution $10^{-3}$ and $10^{-5}$ of each of the samples was spread onto Salmonella-Shigella (SS) agar and thiosulfate citrate bile salt sucrose (TCBS)
(TCBS) agar for the isolation of Salmonella spp. and Shigella spp., and Vibrio spp., consecutively. Plates were incubated at $37^{\circ} \mathrm{C}$ for 24 hours for the detection of typical colonies (23-29).

Preparation of the samples for extraction and conduction of antimicrobial assay. The dried powder form of samples were prepared through grinding and added $10 \mathrm{~g}$ of powder in $100 \mathrm{ml}$ of ethanol and methanol in Durham's bottle which were kept in shaking water bath at $130 \mathrm{rpm}$ for $24 \mathrm{~h}$. at $24{ }^{\circ} \mathrm{C}$. Afterward the extract solution was filtered and the pellet of the samples were collected to observed their anti-bacterial properties against different pathogenic strain (34) by agar well diffusion method $(24,30,35,36)$. At first the lawns of bacterial suspensions $\left(10^{5} \mathrm{cfu}\right.$ or $0.5 \mathrm{OD}$ measured by spectrophotometer) including Escherichia coli, Pseudomonas spp., Shigella spp., Vibrio spp., Klebsiella spp., Staphylococcus aureus, and Salmonella spp. were prepared and $100 \mu l$ of the hot water extract, ethanol- and methanol extracts at a concentration of $\sim 11.1 \mathrm{mg} / \mathrm{ml}$ each were introduced into the wells. Absolute ethanol and methanol were used as negative controls while the antibiotic discs of gentamicin $(10 \mu \mathrm{l})$ were used as positive control. Plates were incubated at $37{ }^{\circ} \mathrm{C}$ for $12-18$ hours and examined for formation of the zone of inhibitions ( $\mathrm{mm}$ ).

\section{RESULTS AND DISCUSSION}

Microbial quality of green bananas and papaya samples. In present study microbial contaminations were evident. All the samples were found to harbor viable bacteria in a range of $10^{4}$ to $10^{7} \mathrm{cfu} / \mathrm{g}$, while fungi were present with in a range of $10^{2}$ to $10^{3} \mathrm{cfu} / \mathrm{g}$ (Table 1 ). All the samples conferred the presence of pathogenic bacteria to some extent. Both green bananas and papaya samples, Staphylococcus spp., Pseudomonas spp. and Vibrio spp. (after enrichment) were predominantly present in all the samples in a range of $10^{2}$ to $10^{3} \mathrm{cfu} / \mathrm{g}$. However, Klebsiella spp. was found only in two green banana samples. On the other hand, all papaya samples harbor Klebsiella spp. within a range of $10^{2}$ to $10^{3} \mathrm{cfu} / \mathrm{g}$ except one sample collected from super shop. No fecal and $E$. coli contamination was found in any samples. Even after enrichment, Salmonella spp. and Shigella spp. was totally absent in all the samples tested (Table 1). Presence of huge loads of microorganisms in green bananas was documented in previous studies (37-40). Findings of the green papaya samples were also in cohort with the previous studies (41-43). Pathogenic proliferations in the green bananas and papaya samples were indicative of improper handling during harvesting, processing, distribution or storage $(24,44,45)$.

In vitro anti-bacterial activity of green banana and papaya samples. Several specialist of herbal and traditional medicines claim the presence of therapeutic properties in preparations from unripe papaya (Carica papaya) ignoring the potential dangers associated with the preparations especially when not consumed fresh (11). The presence of glycosides and alkaloids in banana make them a suitable option in the treatment of some bacterial infections such as cough, fever, cold and venereal diseases (21). The current study was undertaken to investigate the antimicrobial traits of green bananas and papaya samples.

The present investigation revealed that all the samples exhibited antibacterial activity against most of the laboratory strain (Table $2 \& 3$ ). In most cases, the hot water extract of the samples showed no antibacterial 
activity. On the other hand, ethanolic and methanolic extracts of the samples were found to be effective in eliminating pathogens. Only Vibrio spp. was not eliminated by any of the extracts of both samples except green banana from super shops. Overall, all the other samples showed their potential to have antibacterial activity in eliminating pathogens (Tables $2 \& 3$ ). Several studies found significant antimicrobial activity in papaya and bananas against different pathogenic microorganisms $(11,21,46,47)$.

TABLE 1. Microbiological quality of green fruit samples collected from local market, village and super shops

\begin{tabular}{ccccccc}
\hline Sample & $\begin{array}{c}\text { TVB } \\
\text { cfu/g }\end{array}$ & $\begin{array}{c}\text { Fungi } \\
\text { cfu/g }\end{array}$ & $\begin{array}{c}\text { Klebsiella spp. } \\
\text { cfu/g }\end{array}$ & $\begin{array}{c}\text { Staphylococcus spp. } \\
\text { cfu/g }\end{array}$ & $\begin{array}{c}\text { Pseudomonas spp. } \\
\text { cfu/g }\end{array}$ & $\begin{array}{c}\text { Vibrio spp. } \\
\text { cfu/g }\end{array}$ \\
\hline Banana & & & & & & \\
1-B-L & $2.4 \times 10^{7}$ & $6.5 \times 10^{3}$ & $1.0 \times 10^{2}$ & $7.4 \times 10^{3}$ & $1.0 \times 10^{2}$ & $3.7 \times 10^{2}$ \\
2-B-S & $1.5 \times 10^{4}$ & 0 & 0 & 0 & $1.8 \times 10^{3}$ & $2.0 \times 10^{2}$ \\
3-B-S & $5.5 \times 10^{7}$ & $1.4 \times 10^{3}$ & 0 & $8.0 \times 10^{3}$ & $4.8 \times 10^{2}$ & $1.0 \times 10^{2}$ \\
4-B-L & $6.2 \times 10^{5}$ & 0 & 0 & $3.0 \times 10^{2}$ & $1.0 \times 10^{2}$ & $6.0 \times 10^{3}$ \\
5-B-V & $5.0 \times 10^{5}$ & $5.0 \times 10^{2}$ & 0 & $1.5 \times 10^{2}$ & 0 & 0 \\
6-B-V & $6.4 \times 10^{6}$ & $4.8 \times 10^{3}$ & $4.0 \times 10^{2}$ & 0 & $5.2 \times 10^{3}$ & $1.0 \times 10^{2}$ \\
\hline Papaya & & & & & $6.4 \times 10^{3}$ & $1.0 \times 10^{3}$ \\
1-P-V & $5.5 \times 10^{7}$ & $4.3 \times 10^{3}$ & $2.4 \times 10^{2}$ & 0 & $3.2 \times 10^{2}$ & $6.4 \times 10^{2}$ \\
2-P-L & $2.8 \times 10^{7}$ & $1.5 \times 10^{3}$ & $3.5 \times 10^{2}$ & 0 & $4.4 \times 10^{3}$ & $6.8 \times 10^{2}$ \\
3-P-S & $9.0 \times 10^{6}$ & $2.8 \times 10^{3}$ & 0 & $3.6 \times 10^{3}$ & $4.8 \times 10^{3}$ & 0 \\
4-P-S & $7.5 \times 10^{6}$ & $2.8 \times 10^{2}$ & $2.2 \times 10^{2}$ & $1.2 \times 10^{3}$ & $3.2 \times 10^{2}$ & $2.0 \times 10^{2}$ \\
5-P-L & $3.8 \times 10^{7}$ & $3.2 \times 10^{2}$ & $4.2 \times 10^{3}$ & $4.8 \times 10^{3}$ & $4.4 \times 10^{3}$ & 0 \\
6-P-V & $6.4 \times 10^{6}$ & $2.4 \times 10^{2}$ & $9.4 \times 10^{2}$ & $4.0 \times 10^{2}$ & & \\
\hline
\end{tabular}

TVB $=$ Total viable bacteria, $\mathrm{B}=$ Banana, $\mathrm{P}=$ Papaya, $\mathrm{L}=$ Local market, $\mathrm{V}=$ Village, $\mathrm{S}=$ Super shops

Average count (cfu/g) from all samples have been shown here.

E. coli, Salmonella spp., and Shigella spp. were absent in all samples.

TABLE 2. Antimicrobial activity of green banana samples

\begin{tabular}{|c|c|c|c|c|c|c|c|c|c|}
\hline \multirow{3}{*}{ Tested Bacteria } & \multicolumn{9}{|c|}{ zone of inhibition in diameter $(\mathrm{mm})$} \\
\hline & \multicolumn{3}{|c|}{ Green banana (village) } & \multicolumn{3}{|c|}{ Green banana (local market) } & \multicolumn{3}{|c|}{ Green banana (super shop) } \\
\hline & $\begin{array}{c}\text { Hot water } \\
\text { extract }\end{array}$ & $\begin{array}{c}\text { Methanolic } \\
\text { extract }\end{array}$ & $\begin{array}{c}\text { Ethanolic } \\
\text { extract }\end{array}$ & $\begin{array}{c}\text { Hot water } \\
\text { extract }\end{array}$ & $\begin{array}{c}\text { Methanolic } \\
\text { extract }\end{array}$ & $\begin{array}{c}\text { Ethanolic } \\
\text { extract }\end{array}$ & $\begin{array}{c}\text { Hot water } \\
\text { extract }\end{array}$ & $\begin{array}{c}\text { Methanolic } \\
\text { extract }\end{array}$ & $\begin{array}{c}\text { Ethanolic } \\
\text { extract }\end{array}$ \\
\hline Staphylococcus spp. & 0 & $37 \mathrm{~mm}$ & $20 \mathrm{~mm}$ & 0 & 0 & 0 & 0 & 0 & 0 \\
\hline E. coli & 0 & $15 \mathrm{~mm}$ & $25 \mathrm{~mm}$ & 0 & $14 \mathrm{~mm}$ & $20 \mathrm{~mm}$ & 0 & $17 \mathrm{~mm}$ & $18 \mathrm{~mm}$ \\
\hline Klebsiella spp. & 0 & $10 \mathrm{~mm}$ & $17 \mathrm{~mm}$ & 0 & $20 \mathrm{~mm}$ & $25 \mathrm{~mm}$ & 0 & $19 \mathrm{~mm}$ & $28 \mathrm{~mm}$ \\
\hline Salmonella spp. & 0 & $7 \mathrm{~mm}$ & $12 \mathrm{~mm}$ & 0 & $9 \mathrm{~mm}$ & $5 \mathrm{~mm}$ & 0 & $8 \mathrm{~mm}$ & $10 \mathrm{~mm}$ \\
\hline Shigella spp. & 0 & $17 \mathrm{~mm}$ & $43 \mathrm{~mm}$ & 0 & $24 \mathrm{~mm}$ & $5 \mathrm{~mm}$ & 0 & $21 \mathrm{~mm}$ & $9 \mathrm{~mm}$ \\
\hline Pseudomonas spp. & 0 & $19 \mathrm{~mm}$ & $17 \mathrm{~mm}$ & 0 & $13 \mathrm{~mm}$ & $30 \mathrm{~mm}$ & 0 & $11 \mathrm{~mm}$ & $28 \mathrm{~mm}$ \\
\hline Vibrio spp. & 0 & 0 & 0 & 0 & 0 & 0 & 0 & 0 & 0 \\
\hline
\end{tabular}

TABLE 3. Antimicrobial activity of green papaya samples

\begin{tabular}{|c|c|c|c|c|c|c|c|c|c|}
\hline \multirow{3}{*}{ Tested Bacteria } & \multicolumn{9}{|c|}{ Zone of inhibition in diameter ( $\mathrm{mm}$ ) } \\
\hline & \multicolumn{3}{|c|}{ Green papaya (village) } & \multicolumn{3}{|c|}{ Green papaya (local market) } & \multicolumn{3}{|c|}{ Green banana (super shop) } \\
\hline & $\begin{array}{c}\text { Hot water } \\
\text { extract }\end{array}$ & $\begin{array}{c}\text { Methanolic } \\
\text { extract }\end{array}$ & $\begin{array}{c}\text { Ethanolic } \\
\text { extract }\end{array}$ & $\begin{array}{c}\text { Hot water } \\
\text { extract }\end{array}$ & $\begin{array}{c}\text { Methanolic } \\
\text { extract }\end{array}$ & $\begin{array}{c}\text { Ethanolic } \\
\text { extract }\end{array}$ & $\begin{array}{c}\text { Hot water } \\
\text { extract }\end{array}$ & $\begin{array}{c}\text { Methanolic } \\
\text { extract }\end{array}$ & $\begin{array}{c}\text { Ethanolic } \\
\text { extract }\end{array}$ \\
\hline Staphylococcus spp. & 0 & $22 \mathrm{~mm}$ & $20 \mathrm{~mm}$ & 0 & 0 & 0 & 0 & $17 \mathrm{~mm}$ & $13 \mathrm{~mm}$ \\
\hline E. coli & 0 & $17 \mathrm{~mm}$ & $21 \mathrm{~mm}$ & 0 & $19 \mathrm{~mm}$ & $25 \mathrm{~mm}$ & 0 & $24 \mathrm{~mm}$ & $23 \mathrm{~mm}$ \\
\hline Klebsiella spp. & 0 & $9 \mathrm{~mm}$ & $15 \mathrm{~mm}$ & 0 & 0 & 0 & 0 & $15 \mathrm{~mm}$ & $20 \mathrm{~mm}$ \\
\hline Salmonella spp. & 0 & $12 \mathrm{~mm}$ & $5 \mathrm{~mm}$ & 0 & $5 \mathrm{~mm}$ & $7 \mathrm{~mm}$ & 0 & $12 \mathrm{~mm}$ & $11 \mathrm{~mm}$ \\
\hline Shigella spp. & 0 & $19 \mathrm{~mm}$ & $31 \mathrm{~mm}$ & 0 & $21 \mathrm{~mm}$ & $6 \mathrm{~mm}$ & 0 & 0 & 0 \\
\hline Pseudomonas spp. & 0 & $21 \mathrm{~mm}$ & $19 \mathrm{~mm}$ & 0 & $11 \mathrm{~mm}$ & $29 \mathrm{~mm}$ & 0 & $11 \mathrm{~mm}$ & $29 \mathrm{~mm}$ \\
\hline Vibrio spp. & 0 & 0 & 0 & 0 & 0 & 0 & 0 & $9 \mathrm{~mm}$ & $7 \mathrm{~mm}$ \\
\hline
\end{tabular}




\section{CONCLUSIONS}

Presence of pathogenic bacteria in extensive amount in fresh fruits or vegetables is not desirable in any condition which may cause food-borne illness in human. Government should take some necessary steps in agriculture sector to reduce the health risk factors by food-borne illness. Collectively, all the samples exhibited significant antibacterial activity as revealed from agar well diffusion method. However, presence of anti-bacterial traits of the samples ensured presence of antibacterial substance in fruits samples. Despite the significant progress made in microbiology and the control of microorganisms, drug resistant microorganisms have become a major threat to public health. The use of medicinal fruits or vegetables with antimicrobial activity requires more attention to combat the situation.

\section{ACKNOLEDGEMENT}

Authors thank Stamford University Bangladesh for the laboratory facilities and financial support.

\section{REFERENCES}

1. Beuchat LR. 1998. Surface decontamination of fruits and vegetables eaten raw: A review. WHO/FSF/FOS/98.2, Food Safety Unit, World Health Organisation, Geneva, Switzerland.

2. World Health Organization (WHO). 2004. Diet, nutrition and the prevention of chronic diseases. Report of a Joint FAO/WHO Expert Consultation, World Health Organization, Geneva, Switzerland.

3. Grace D, Makita K, Kang'ethe E, Bonfoh B. 2010. Safe food, fair food: Participatory risk analysis for improving the safety of informally produced and marketed food in Sub-saharan Africa. Rev. Afr. Santé Prod. Anim. 8: 3-11.

4. Fletcher SM, McLaws ML, Ellis JT. 2013. Prevalence of gastrointestinal pathogens in developed and developing countries: Systematic review and meta-analysis. J. Pub. Health Res. 2: 42-53.

5. Husain MD, William R. 2010. Status of banana cultivation and disease incidences in Malaysia. Crop Protection and Plant Quarantine Division, Department of Agriculture, Malaysia.

6. Chai M, Ho YW, Liew KW, Asif JM. 2004. Banana improvement: Cellular, molecular biology and induce mutations. Science Publisher Inc., USA.

7. Arumugam R, Manikandan M. 2011. Fermentation of pretreated hydrolyzates of banana and mango fruit wastes for ethanol production. Asian J. Biol. Sci. 2: 246-256.

8. Chandler S. 1995. Bananas and plantains. London.

9. Honfo FG, Kayodé AP, Coulibaly O, Tenkouano A. 2007. Relative contribution of banana and plantain products to the nutritional requirements for iron, zinc and vitamin $\mathrm{A}$ of infants and mothers in Cameroon. Fruits. 62: 267-277.

10. IITA. 2000. Improving plantain and banana based. IITA, Ibadan.

11. Amosu AM, Degun AM, Esan EB. 2014. Microbial contaminants in the herbal preparation from green pawpaw fruits. Biomed. Res. 25 (4): 169178.

12. Oranusi S, Galadima M, Umoh VJ, Nwanze, PI. 2007. Food safety evaluation in boarding schools in Zaria, Nigeria, using the HACCP system. Sci. Res. Essay. 2 (10): 426-433.

13. Ofor MO, Okorie VC, Ibeawuchi II, Ihejirika GO, Obilo OP, Dialoke SA. 2009. Microbial contaminants in fresh fruit wash water and food safety considerations in South-Eastern Nigeria. Life Sci. J. 1: 80-82.

14. Talaro A. 1996. Foundations in microbiology, $2^{\text {nd }}$ ed. Mc- Graw Hill, USA.

15. Kanazawa, K, Sakakibara H. 2000. High content of dopamine, a strong antioxidant, in Cavendish banana. J.Agricul. Food Chem. 48: 844-848.

16. Someya S, Yoshiki Y, Okubo K. 2002. Antioxidant compounds frombananas (MusaCavendish). Food Chem. 79: 351-354.
17. Brooks AA. 2008. Ethanol production potential of local yeast strains isolated from ripe banana peels. African J. Biotechnol. 7: 3749-3752.

18. Ponnuswamy V, Lekshmi VD, Prakash SGV. 2011. Bio-processing of banana peel for amylase production by Sp. Penicillium. Asian J. Biol. Sci. 2: 257-264.

19. Mc Laughlin JL, Ratanyake S, Rupprecht JK, Potter WM. 1992 Evaluation of various parts of paw-paw tree, Asimma tritoba as commercial source of the pestiside annonsceae acetogenins. J. Econ. Entomol. 85: 23532356.

20. Elizabeth K. 1994. Immense help from nature's workshop, $1^{\text {st }}$ ed. Elikaf Health Services LTD. Ikeja, Lagos.

21. Ehiowemwenguan G,Emoghene AO, Inetianbor JE. 2014. Antibacterial and phytochemical analysis of Banana fruit peel. IOSR J Pharm. 4 (8): 18-25.

22. Ifesan BOT. 2013. Antioxidant and antimicrobial properties of selected plant leaves. European Journal of medicinal plants. 3 (3): 465-473

23. Cappuccino JG, Sherman N. 1996. Microbiology - A laboratory manual. The Benjamin/Cummings Publishing Co., Inc., Menlo Park, California.

24. Sharmin M, Nur IT, Acharjee M, Munshi SK, Noor R. 2014 Microbiological profiling and the demonstration of in vitro anti-bacterial traits of the major oral herbal medicines used in Dhaka Metropolis. SpringerPlus. 3 : 739.

25. Das NC, Hossaini F, Munshi SK. 2017. Influence of tannery wastes and the surrounding environment of tannery industries on microbial growth and proliferation. Stam. J. Microbiol. 7 (1): 14-18.

26. Acharjee M, Ahmed E, Munshi SK, Noor R. 2014. Validation of $\boldsymbol{\gamma}$ irradiation in controlling microorganisms in fish. Nutri. Food. Sci. 44 (3): 258-266.

27. Marjan S, Das KK, Munshi SK, Noor R. 2014. Drug-resistant bacterial pathogens in milk and some milk products. Nutrn. Food Sci. 44 (3): 241-248.

28. Ahmed T, Baidya S, Sharma BC, Malek M, Das KK, Acharjee M, et al 2013. Identification of drug-resistant bacteria among export quality shrimp samples in Bangladesh. Asian J. Microbiolol. Biotechnol. Environ. Sci. 15 (4): $31-36$.

29. Noor R, Acharjee M, Ahmed T, Das KK, Paul L, Munshi SK, et al. 2013. Microbiological study of major sea fish available in local markets of Dhaka city, Bangladesh. J. Microbiol. Biotechnol. Food Sci. 2 (4): 2420-2430.

30. Ahmed T, Urmi NJ, Munna MS, Das KK, Acharjee M, Rahman MM, et al. 2014. Assessment of microbiological proliferation and in vitro demonstration of the antimicrobial activity of the commonly available salad vegetables within Dhaka metropolis, Bangladesh. Am. J. Agri. Forestr. 2 (3): 55-60.

31. Rahman F. Noor R. 2012. Prevalence of pathogenic bacteria in common salad vegetables of Dhaka Metropolis. Bangladesh. J. Botany. 41 (2): 159162.

32. Colwell RR. 2000. Non-culturable microorganisms in the environment. American Society of Microbiology, Washington DC, USA.

33. Oliver JD. 2005. The viable but nonculturable state in bacteria. J. Microbiol 43: $93-100$.

34. Angiolella L, Sacchetti G, Efferth T. 2018. Antimicrobial and antioxidant activities of natural compounds. Evidence-Based Complement. Alt. Med. 2018. 1945179.

35. Jagessar RC, Mars A, Gones G. 2008. Selective antimicrobial properties of leaf extract against various micro-organisms using disc diffusion and agar well diffusion method. J. Nat. Sci. 6 (2): 24-38, 2008.

36. Hussain A, Wahab S, Zarin I, Hussain MDS. 2010. Antibacterial activity of the leaves of Coccinia indica (W. and A) W of India. Adv. Biol. Res. 4 (5): 241-248.

37. Pitt JI, Hocking AD. 2009. Fungi and food spoilage. New York.

38. Moreno MR, Sarantinopoulos P, Tsakalidou E, DeVuyst L. 2006. The role and application of enterococci in food and health. Int. J. Food Microbiol. 106: $1-24$

39. Rose-Monde M, Séverin KKA, Lessoy Z, Edwige A, Koffi Y, Sébastien NL. 2013. Microbiological safety and quality assessment of a very appreciate traditional ready to eat plantain food, sold in retails markets. African J. Microbiol. Res. 7 (32): 4123-4129.

40. Endtz HP, Braak V, Verbrugh N, Belkum HA. 1999. Vancomycin resistance: status quo and quo vadis. Eur. J. Clin. Microbiol. Infect. Dis. 18: 683-690.

41. Baiyewu RA, Amusa NA, Ayoola OA, Babalola AA. 2007. Survey of the post harvestdiseases and aflatoxin contamination of marketedpawpaw fruit (Carica papaya L) in South WesternNigeria. African J. Agric. Res. 2 (4): 178181.

42. Gupta AK, Pathak VN. 1986. Survey of fruit market for papaya fruit rot by fungi pathogens Indian J. Mycol. 16: 152-154.

43. Oyeniyi OS. 1992. Microflora in the rhizosphere of pawpaw tree. A Final Diploma thesis in the Laboratory Technology Training School, University of Ibadan, Ibadan, Nigeria.

44. Duraisankar M, Ravindran AD. 2013. Microbial quality of herbal medicine in production unit. Int. J. Pharm. Life Sci. 4 (7): 2775-2779. 
45. World Health Organization (WHO). 2007. WHO guidelines for assessing quality of herbal medicines with reference to contaminants and residues. WHO press, Geneva, Switzerland.

46. Ikeyi AP, Ogbonna AO, Eze F. 2013. Phytochemical analysis of paw paw (Carica papaya) leaves. IJLBPR. 2 (3): 347-351.
47. Singh B, Bhat TK. 2003. Potential therapeutic applications of some antinutritional plant secondary metabolites. J. Agri. Food Chem. 51: 55795597. 